\title{
USE OF YACON IN NATURA AND ITS FLOUR IN THE DEVELOPMENT OF DIET AND CONVENTIONAL CAKES
}

\section{USO DO YACON IN NATURA E EM FARINHA NO DESENVOLVIMENTO DE BOLOS DIET E CONVENCIONAL}

\author{
Larissa Scarparo Rocha ${ }^{1}$; Raianny da Silva ${ }^{1}$; Erika Madeira Moreira da Silva ${ }^{2}$ \\ 1. Federal University of Espirito Santo - UFES, Center of Agricultural Sciences, Alegre, ES, Brazil; \\ 2. Professor, PhD, Federal University of Espirito Santo (UFES), Center of Health Sciences. Maruípe - Vitória, ES, Brazil. \\ erika.alimentos@gmail.com
}

\begin{abstract}
Yacon is a tuberous root that has bioactive components in its composition, such as fructooligosaccharides (FOS). The objective of this study was to evaluate physicochemical and sensory characteristics of diet and conventional cakes made with yacon in natura and its respective flour. Cakes were prepared in chocolate and carrot flavors with the addition of $50 \%$ yacon in natura and $70 \%$ yacon flour. Cakes prepared with $50 \%$ yacon in natura with the addition of sucrose in the formula showed physical aspects closer to conventional cakes. The yield of the cakes was considered satisfactory at around $90 \%$, regardless of yacon in natura or yacon flour usage. The chocolate cakes had higher ratings regarding the sensory attributes and the purchase intent in relation to the carrot cakes, especially when using yacon in natura in the formula. The cakes containing sweetener were rated as good as those with sucrose, especially in regards to the flavor of the chocolate cakes. According to the chemical composition, cakes with $70 \%$ yacon flour had higher dietary fiber content as well as FOS, giving credit to their claim as a bioactive component.
\end{abstract}

KEYWORDS: Smallanthus sonchifolius. Cakes. Chemical composition. Nutrition. Bioactive. Fructooligosaccharides.

\section{INTRODUCTION}

Yacon (Smallanthus sonchifolius Poepp. Endl) is a tuberous root from the Asteraceae family found in the Andes region and introduced in Brazil in the 90s by Japanese immigrants in the state of São Paulo (SANTANA; CARDOSO, 2008). Yacon roots have a long history of safe use in South America and elsewhere with potential health-promoting properties, including prebiotic, antidiabetic, antioxidative and antimicrobial effects (OJANSIVU et al., 2011).The characteristic sweetness is related to the presence of carbohydrates, particularly in the form of fructooligosaccharides (FOS) (DELGADO et al., 2013). FOS is a soluble dietary fiber, belonging to fructans class, with prebiotic properties since they are not digested by enzymes of the human digestive tract, but are fermented in the colon by intestinal health promoting bacteria, especially by the bifidobacteria and lactobacilli, stimulating their growth and activity and inhibiting Clostridium, Salmonella, Shigella, Listeria, Campylobacter and Coliform (CAMPOS et al., 2012). This prebiotic also works to reduce the risk of cancer, improves bowel function, has cholesterol lowering effect and improves the immune response (VOS et al., 2007).
Yacon has been used as a food supplement in the preparation of different products for presenting contents of oligofructans (FOS) which may vary from $19 \%$ (VASCONCELOS et al., 2010) to $44 \%$ (GENTA et al., 2005), depending on the cultivation period, harvest, storage duration and conditions. This tuberous root has been used as an ingredient in various formulas, such as cakes (ROSA et al., 2009; MOSCATTO et al., 2004), jams (SALVADOR et al., 2012), bread (ROLIM et al., 2011), yogurt (VASCONCELOS, 2010), juices (GUIMARÃES; BOEKEL, 2006) and candies (MALDONADO; SINGH, 2008), both in natura and as flour.

Products prepared with ingredients in the form of flour have a longer shelf life when compared to in natura products with higher moisture content. However, the use of in natura ingredients becomes an alternative that is easy to reproduce, particularly for homemade preparation. In this context, the objective of this study was to evaluate physicochemical and sensory characteristics of diet and conventional cakes made with yacon, noting possible differences in the use of this tuber both in its in natura form and as flour. 
Use of yacon in natura...

\section{MATERIAL AND METHODS}

\section{Yacon flour processing}

Yacon (Smallanthus sonchifolia Poepp. Endl)

was acquired from CEASA (Central de Abastecimento) in Cariacica (Espirito Santo - Brazil). The tubers were washed and sanitized in a sodium hypochlorite solution at $200 \mathrm{mg} / \mathrm{L}$ for 15 minutes. They were peeled with a potato peeler and processed according to the preliminary tests. The tests were conducted in order to avoid the enzymatic browning that is expected during the drying process of fruits and vegetables. This way, different treatments were applied, considering different ways of yacon processing (REBELO; CASALI; BERTOLDI, 2008; PADILHA et al., 2008; SARAIVA et al., 2011). Among the performed tests with yacon, the treatment using citric acid was capable to produce a product almost free of browning keeping visual features and thus, a lighter flour. The yacon was cooked with the peel (for 2 minutes), which was removed by friction. Afterwards, it was cut into slices (chips) of $2 \mathrm{~mm}$ by using stainless steel knives. The tubers were placed in a $1 \%$ citric acid solution for 20 seconds. Later on, they were drained and put in a tray dryer with air circulation at $60^{\circ} \mathrm{C}$ during 24 hours and grinded in a disc mill in order to obtain the flour. Then, they were packed in vacuum sealed plastic bags, properly labeled and kept in a dry and ventilated place. The flour yield was calculated by the following formula: $\% \mathrm{Y}=$ (flour weight $\mathrm{x} 100) /$ pulp weight.

\section{Development of cakes}

Two cake flavors were prepared: chocolate and carrot. Both flavors were formulated containing yacon in natura and yacon flour (a treatment containing sucrose in the formula and another treatment using the artificial sweetener as a sucrose substitute). Also, control cakes (without the addition of yacon) were prepared. The proportions of yacon as well as other ingredients can be checked in Table 1. A proportion of 50\% yacon in natura was used in relation to the total wheat flour, and for the formula of the cakes with flour, different tests were performed with different percentages of it replacing wheat. These percentages were $50 \%, 60 \%, 70 \%, 80 \%$ and $100 \%$ in order to add more than $40 \%$ content to the formula, which was used in the study of Padilla et al. (2010). The formula containing $70 \%$ yacon flour in the
ROCHA, L. S.; SILVA, R.; SILVA, E. M. M.

preliminary tests showed typical characteristics of a cake. The sensory characteristics were significantly altered when above that percentage (data visually analyzed). Thus, the liquid ingredients were blended and placed in a container after being homogenized, where the dry ingredients were added. After mixing, the dough was placed in a greased cake pan and taken to a preheated oven for 40 minutes at $180{ }^{\circ} \mathrm{C}$.

\section{Physical characteristics}

Six cakes of each preparation from the same batch were analyzed according to the methodology proposed by the American Association of Cereal Chemists - AACC (1995). The weight loss was measured in a RadWag ${ }^{\circledR}$ scale, model WPT-6C/1 $(0.1 \mathrm{~g})$. The apparent volume (increase of volume) was measured, where the height reached by the cake was marked on the cake pan used. The cake pans were filled with water to the marks and the volume was measured in the measuring cylinder. The difference between the pre and post-baking volumes was calculated and expressed in milliliter. The thermal factor and the yield of the formulas were calculated according to Araújo and Guerra (1995).

\section{Sensory analysis}

Sensory analysis was conducted on four different days as the number of samples could overload the judges and adversely affect the results. Thus, the judges could evaluate the cakes with yacon in natura on two different days (one flavor for each day) and the cakes with yacon flour on another two days, as well as their respective controls. The cakes were evaluated by an acceptability test through a nine point hedonic scale $(9=\mathrm{I}$ really liked it and $1=\mathrm{I}$ really disliked it) according to the following attributes: appearance, flavor, color, texture and overall acceptance (DUTKOSKI, 2007). Furthermore, the purchase intent was also evaluated using a nine point scale $(9=\mathrm{I}$ would definitely buy it and $1=\mathrm{I}$ would definitely not buy it). Sixty non-trained judges took part in these tests, all of them aged 18 years or older that enjoy cakes and signed a Consent Form. The current study was approved by the Research Ethics Committee of the Espírito Santo North University Center - CEUNES (Espírito Santo Brazil) (n $n^{\circ}$ 051/2011). 
Table 1. Ingredients used in the development of cakes with yacon in natura and yacon flour.

\begin{tabular}{|c|c|c|c|c|c|c|c|c|c|c|c|c|}
\hline \multirow{2}{*}{ Ingredients } & \multicolumn{6}{|c|}{ Formulations (chocolate flavor) } & \multicolumn{6}{|c|}{ Formulations (carrot flavor) } \\
\hline & $\mathrm{CChCSu}$ & $\mathrm{CChCSw}$ & $\mathrm{T} 1$ & $\mathrm{~T} 2$ & T3 & $\mathrm{T} 4$ & $\mathrm{CCaCSu}$ & $\mathrm{CCaCSw}$ & $\mathrm{C} 1$ & $\mathrm{C} 2$ & $\mathrm{C} 3$ & $\mathrm{C} 4$ \\
\hline Wheat flour (g) & 200.0 & 200.0 & 200.0 & 60.0 & 200.0 & 60.0 & 200.0 & 200.0 & 200.0 & 60.0 & 200.0 & 60.0 \\
\hline Cocoa powder $(\mathrm{g})$ & 94.0 & 94.0 & 94.0 & 94.0 & 94.0 & 94.0 & - & - & - & - & - & - \\
\hline Carrot $(\mathrm{g})$ & - & - & - & - & - & - & 135.8 & 135.8 & 135.8 & 135.8 & 135.8 & 135.8 \\
\hline Boiling water $(\mathrm{mL})$ & 180.0 & 180.0 & 180.0 & 180.0 & 180.0 & 180.0 & - & - & - & - & - & - \\
\hline Sucrose $(g)$ & 140.0 & 0 & 140.0 & 140.0 & 0 & 0 & 164.0 & 0 & 164.0 & 164.0 & 0 & 0 \\
\hline Sweetner in powder** $(\mathrm{g})$ & 0 & 19.0 & 0 & 0 & 19.0 & 19.0 & 0 & 22.0 & 0 & 0 & 22.0 & 22.0 \\
\hline Yacon in natura $(\mathrm{g})$ & 0 & 0 & 100.0 & 0 & 100.0 & 0 & 0 & 0 & 100.0 & 0 & 100.0 & 0 \\
\hline Yacon flour (g) & 0 & 0 & 0 & 140.0 & 0 & 140.0 & 0 & 0 & 0 & 140.0 & 0 & 140.0 \\
\hline Vegetable oil (mL) & 80.0 & 80.0 & 80.0 & 80.0 & 80.0 & 80.0 & 120.0 & 120.0 & 120.0 & 120.0 & 120.0 & 120.0 \\
\hline Baking powder (g) & 15.0 & 15.0 & 15.0 & 15.0 & 15.0 & 15.0 & 16.0 & 16.0 & 16.0 & 16.0 & 16.0 & 16.0 \\
\hline Egg (unit) & 2.0 & 2.0 & 2.0 & 2.0 & 2.0 & 2.0 & 2.0 & 2.0 & 2.0 & 2.0 & 2.0 & 2.0 \\
\hline Salt (g) & 0.6 & 0.6 & 0.6 & 0.6 & 0.6 & 0.6 & - & - & - & - & - & - \\
\hline
\end{tabular}

*CChCSu (control chocolate cake with sucrose), CChCSw (control chocolate cake with sweetner), T1 (chocolate cake with $50 \%$ yacon in natura and with sucrose), T2 (chocolate cake with 70\% yacon flour and sucrose), T3 (chocolate cake with 50\% yacon in natura and sweetner), T4 (chocolate cake with $70 \%$ yacon flour and sweetner). CCaCSu (control carrot cake with sucrose), CCaCSw (control carrot cake with sweetner), C1 (carrot cake with $50 \%$ yacon in natura and with sucrose), C2 (carrot cake with $70 \%$ yacon flour and with sucrose), C3 (carrot cake with $50 \%$ yacon in natura and with sweetner), C4 (carrot cake with $70 \%$ yacon flour and with sweetner). ** Sweetener in powder consisting of cyclamate and saccharin suitable for cooking. 


\section{Chemical characterization}

Cakes selected by the sensory analysis were evaluated by their proximate composition, in triplicate, according to the Association of Official Agricultural Chemists - AOAC (2005) methods: moisture, determined in an oven at $105{ }^{\circ} \mathrm{C}$ until constant weight; protein by the Kjeldahl method using the factor 6.25; lipids by the method of extraction with petroleum ether in a Soxhlet equipment; and ash by burning the sample in an oven at $550{ }^{\circ} \mathrm{C}$ until constant weight. The dietary fiber content of the cakes was determined by the enzymatic-gravimetric method of the AOAC (2005). The oligofructan content was determined by High Performance Liquid Chromatography (HPLC) using an Alliance chromatograph (model Waters 2695) with an Alliance fluorescence detector (model Waters 2475) - USA, according to the methodology used by Rodrigues et al. (2001) and Vasconcelos et al. (2010). A commercial oligofructose sample with $85 \%$ purity was used as standard. Available carbohydrates were calculated by difference: $100-$ (moisture + proteins + lipids + ash + fiber). Total carbohydrates were calculated excluding fiber content. The energetic value was determined in Kcal.

\section{Data analysis}

The results were grouped using Excel 2007 and submitted to analysis of variance (ANOVA) followed by the average comparison test (Tukey) at 5\% probability, using Statistica 10.0 software.

\section{RESULTS AND DISCUSSION}

\section{Yacon flour yield}

After obtaining yacon flour, the yield was $10.5 \%$, very close to values found in other research (RIBEIRO, 2008; SANTANA; CARDOSO, 2008; PADILHA et al., 2009).

\section{Physical characterization}

Results from the physical characterization of cakes prepared with yacon can be seen in Table 2 . Among the chocolate cakes made with yacon, sample $\mathrm{T} 1$ had the greatest post-baking weight loss, which was similar $(\mathrm{P}>0.05)$ to the control samples $(\mathrm{CchCSu}$ and $\mathrm{CChCSw}$ ). The results of the volume increase in samples T1 and T2 (both with sucrose in the formulation) were similar to the control sample with sucrose $(\mathrm{CChCSu})$ with the highest volume gain among treatments. That is, even losing less weight,
ROCHA, L. S.; SILVA, R.; SILVA, E. M. M.

sample T2 increased its volume resulting in a more aerated and soft product (data visually analyzed). When sucrose was replaced by the sweetener, samples T3 and T4 lost less weight and had lower volumes, resulting in cakes with an internal structure with fewer openings and "heavy" aspect.

According to Akesowan (2009), this phenomenon can be explained by the lower capacity of the used sweetener to retain air. Furthermore, one of the sucrose functions is to provide softness and volume increase to the dough (ESTELLER et al., 2004). Additionally, sucrose is an important substrate for yeast growth during fermentation, contributing to gas production and consequently increasing cake volume. Although cakes made with yacon had less weight loss, they had similar yields to each other, including greater yields than the control sample with sucrose. The same effect was also evident for the thermal factor, since this is related to how much the cakes yield. The weight loss during baking demonstrates the ability of the dough to retain water, while the volume becomes important to verify the flour's ability to expand and retain the gas within the dough during baking (ESTELLER; LANNES, 2005). Thus, considering the ingredients used in the formulas for chocolate cakes, samples T1 (prepared with yacon in natura and sucrose) and T2 (prepared with yacon flour and sucrose) are those that are closer to the desirable characteristics for cakes, as moderate weight loss (thus avoiding excessively humid and heavy cakes) and increases in post-baking volume, resulting in a product with good volume increase, homogeneity and the typical aerated structure.

Unlike the chocolate cakes, carrot cakes had less weight loss and greater volume gain for most samples, except treatment C4 (Table 2). The variations in the physical characteristics of carrot cakes, regarding chocolate cakes, were mostly due to the ingredients used in the formulation of the cakes. Among the cakes made with yacon in natura, the one with sucrose $(\mathrm{C} 1)$ had a greater weight loss, similar to its control $(\mathrm{CCaCSu})$. However, among the cakes made with yacon flour, the one made with sweetener (C4) had greater weight loss, but less than its control (CCaCSw). Furthermore, sample $\mathrm{C} 4$ had a lower post-cooking volume among all samples, resulting in "heavy" cakes. Other carrot cakes have a similar volume increase among themselves ranging between 360 and 436 mililiters, but less than the control sample with sucrose (CCaCSu). When sucrose is 
replaced or removed from the formulation of breads and cakes, the dilution of gluten-forming proteins may occur and it may lead to decreased volume and change in the final product texture (GOMEZ et al., 2003). Silva et al. (2010) showed a greater volume increase in breads made with FOS, whose formula contained sucrose. Sample C1 showed both the highest yield and thermal factor. However, the other treatments were very similar, including the controls.

\section{Sensory evaluation}

The results of sensory evaluation of all prepared cakes are shown in Table 3. To clarify the discussion, the results and discussion are divided into cakes made with yacon in natura and cakes made with yacon flour. The results were analyzed according to each day of sensory evaluation.

\section{Cakes made with yacon in natura (1st and 2nd days of analysis)}

Regarding the taste of chocolate cakes, only sample T1 obtained a significantly lower result $(\mathrm{P}<0.05)$ to its control $(\mathrm{CChCSu})$. Cakes made with sweetener had a good evaluation in the corresponding hedonic scale between "like moderately" and "really liked" being similar to their respective control $(\mathrm{CChCSw})$. This feature is interesting since bakery products containing sucrose usually tend to have better evaluation when compared with products containing a sweetener. Regarding the purchase intent, it could be observed the interest in purchasing the product if it were available on the market. In assessing the taste of carrot cake made with yacon in natura (Table 3), a significant difference between the cakes containing yacon and their respective controls was not observed. On the other hand, cakes made with sucrose showed better evaluation in this aspect. When analyzing the texture, the carrot cake made with yacon in natura and sweetener was better rated than its respective control. However, the control sample with sucrose (CCaCSu) was the one that had the best average. Regarding the appearance, color and overall acceptability, the control cake with sucrose $(\mathrm{CCaCSu})$ got the best average compared to the other treatments. Regarding the purchase intent, the judges showed doubt about the acquisition of cakes made with yacon.

\section{Cakes made with yacon flour (3rd and 4th days of analysis)}

ROCHA, L. S.; SILVA, R.; SILVA, E. M. M.

With regards to the texture and appearance of the chocolate cakes, the control cake with sucrose $(\mathrm{CCaCSu})$ had the highest average, similar to cakes made with sweetener (control CChCSw and T4). Compared to other attributes, there were no differences of significance between treatments $(\mathrm{P}>0.05)$. The judges showed a tendency to purchase these cakes, according to the assessment of the purchase intent, unlike the study of Padilha et al. (2010). Moscatto et al. (2004) showed in chocolate cakes made with $20 \%$ and $40 \%$ of yacon flour (with sucrose) that the attributes color and overall acceptability did not differ statistically from the control samples. In contrast, cakes made with $20 \%$ yacon flour had better reviews regarding taste. In assessing carrot cakes made with $70 \%$ yacon flour, samples $\mathrm{C} 2$ and $\mathrm{C} 4$ showed lower averages than their respective controls ( $\mathrm{CCaCSu}$ and $\mathrm{CCaCSw}$ ). The judges were unsure about the acquisition of carrot cakes made with yacon flour. This fact can be explained by the darkened appearance of the cake when the yacon flour was added.

\section{Chemical characterization}

The results of chemical characterization of chocolate and carrot cakes are shown in Table 4. The moisture content in the samples ranged from 19.87 to $43.90 \%$, while the cakes made with yacon in natura showed higher moisture contents, especially diet cakes (with sweetener). This can be primarily explained by the high moisture content in the root in its in natura form which is $91.1 \%$ (VASCONCELOS et al., 2010). Furthermore, the presence of hydroxyl groups available in the composition of FOS present in yacon can interact with water through hydrogen bonding, hindering its evaporation during cooking (ROBERFROID; GIBSON; DELZENNE, 1993). 
Table 2. Physical characteristics of cakes made with yacon in natura and yacon flour.

\begin{tabular}{|c|c|c|c|c|c|c|c|c|c|c|c|c|}
\hline \multirow{2}{*}{$\begin{array}{l}\text { Physical } \\
\text { charac- } \\
\text { teristics }\end{array}$} & \multicolumn{6}{|c|}{ Formulations (chocolate flavor) } & \multicolumn{6}{|c|}{ Formulations (carrot flavor) } \\
\hline & CChCSu & $\mathrm{CChCSw}$ & $\mathbf{T 1}$ & $\mathbf{T 2}$ & T3 & $\mathbf{T 4}$ & $\mathrm{CCaCSu}$ & $\mathrm{CCaCSw}$ & C1 & $\mathbf{C 2}$ & C3 & C4 \\
\hline $\begin{array}{l}\text { Weight } \\
\text { loss (g) }\end{array}$ & $\begin{array}{c}164.66 \pm \\
1.11^{\mathrm{a}}\end{array}$ & $\begin{array}{c}86.50 \pm \\
1.16^{\mathrm{b}}\end{array}$ & $\begin{array}{c}106.80 \pm \\
1.41^{\mathrm{ab}}\end{array}$ & $\begin{array}{c}60.54 \pm \\
1.89^{c}\end{array}$ & $\begin{array}{c}52.00 \pm \\
1.30^{\mathrm{c}}\end{array}$ & $\begin{array}{c}52.43 \pm \\
1.08^{\mathrm{c}}\end{array}$ & $\begin{array}{c}38.56 \pm \\
1.08^{b}\end{array}$ & $\begin{array}{c}54.37 \pm \\
1.98^{\mathrm{a}}\end{array}$ & $\begin{array}{c}39.10 \pm \\
1.07^{\mathrm{b}}\end{array}$ & $\begin{array}{c}19.97 \pm \\
1.57^{\mathrm{c}}\end{array}$ & $\begin{array}{c}15.10 \pm \\
1.87^{\mathrm{c}}\end{array}$ & $\begin{array}{c}39.56 \pm \\
1.57^{\mathrm{b}}\end{array}$ \\
\hline $\begin{array}{l}\text { Volume } \\
\text { increase } \\
(\mathrm{mL})\end{array}$ & $\begin{array}{c}405.33 \pm \\
0.01^{\mathrm{a}}\end{array}$ & $\begin{array}{c}205.34 \pm \\
1.30^{\mathrm{b}}\end{array}$ & $\begin{array}{c}251.33 \pm \\
0.57^{\mathrm{ab}}\end{array}$ & $\begin{array}{c}327.34 \pm \\
1.14^{\mathrm{ab}}\end{array}$ & $\begin{array}{c}190.00 \pm \\
1.63^{\mathrm{b}}\end{array}$ & $\begin{array}{c}192.66 \pm \\
1.21^{\mathrm{b}}\end{array}$ & $\begin{array}{c}729.33 \pm \\
1.71^{\mathrm{a}}\end{array}$ & $\begin{array}{c}382.00 \pm \\
1.58^{\mathrm{b}}\end{array}$ & $\begin{array}{c}390.67 \pm \\
1.01^{\mathrm{b}}\end{array}$ & $\begin{array}{c}360.66 \pm \\
0.01^{\mathrm{b}}\end{array}$ & $\begin{array}{c}436.33 \pm \\
1.37^{\mathrm{b}}\end{array}$ & $\begin{array}{c}80.66 \pm \\
1.62^{\mathrm{c}}\end{array}$ \\
\hline $\begin{array}{l}\text { Yield } \\
(\%)\end{array}$ & $\begin{array}{c}80.94 \pm \\
1.26^{\mathrm{b}}\end{array}$ & $\begin{array}{c}110.08 \pm \\
0.43^{\mathrm{a}}\end{array}$ & $\begin{array}{c}92.76 \pm \\
0.76^{\mathrm{a}}\end{array}$ & $\begin{array}{c}90.51 \pm \\
0.31^{\mathrm{a}}\end{array}$ & $\begin{array}{c}92.61 \pm \\
0.28^{\mathrm{a}}\end{array}$ & $\begin{array}{c}89.70 \pm \\
0.20^{\mathrm{a}}\end{array}$ & $\begin{array}{c}94.60 \pm \\
0.32^{\mathrm{b}}\end{array}$ & $\begin{array}{c}92.27 \pm \\
0.42^{\mathrm{b}}\end{array}$ & $\begin{array}{c}106.83 \pm \\
1.35^{\mathrm{a}}\end{array}$ & $\begin{array}{c}92.42 \pm \\
0.37^{\mathrm{b}}\end{array}$ & $\begin{array}{c}95.33 \pm \\
1.68^{\mathrm{b}}\end{array}$ & $\begin{array}{c}94.36 \pm \\
0.55^{\mathrm{b}}\end{array}$ \\
\hline $\begin{array}{l}\text { Thermal } \\
\text { factor }\end{array}$ & $\begin{array}{l}0.80 \pm \\
0.12^{b}\end{array}$ & $\begin{array}{l}1.10 \pm \\
0.04^{\mathrm{a}}\end{array}$ & $\begin{array}{c}0.92 \pm \\
0.00^{\mathrm{a}}\end{array}$ & $\begin{array}{c}0.90 \pm \\
0.00^{\mathrm{a}}\end{array}$ & $\begin{array}{c}0.92 \pm \\
0.00^{\mathrm{a}}\end{array}$ & $\begin{array}{c}0.89 \pm \\
0.00^{\mathrm{a}}\end{array}$ & $\begin{array}{l}0.94 \pm \\
0.00^{\mathrm{b}}\end{array}$ & $\begin{array}{l}0.92 \pm \\
0.00^{\mathrm{b}}\end{array}$ & $\begin{array}{l}1.06 \pm \\
0.01^{\mathrm{a}}\end{array}$ & $\begin{array}{l}0.92 \pm \\
0.00^{\mathrm{b}}\end{array}$ & $\begin{array}{l}0.95 \pm \\
0.01^{\mathrm{b}}\end{array}$ & $\begin{array}{l}0.94 \pm \\
0.00^{\mathrm{b}}\end{array}$ \\
\hline
\end{tabular}

*CChCSu (control chocolate cake with sucrose), CChCSw (control chocolate cake with sweetner), T1 (chocolate cake with 50\% yacon in natura and with sucrose), T2 (chocolate cake with $70 \%$ yacon flour and sucrose), T3 (chocolate cake with 50\% yacon in natura and sweetner), T4 (chocolate cake with $70 \%$ yacon flour and sweetner). CCaCSu (control carrot cake with sucrose), CCaCSw (control carrot cake with sweetner), C1 (carrot cake with 50\% yacon in natura and with sucrose), C2 (carrot cake with $70 \%$ yacon flour and with sucrose), $\mathbf{C 3}$ (carrot cake with 50\% yacon in natura and with sweetner), $\mathbf{C 4}$ (carrot cake with $70 \%$ yacon flour and with sweetner). *Same letters in the same line indicate no significant difference between the results, considering $\mathrm{p}>0.05$ (Tukey test) 
Table 3. Sensory evaluation of cakes made with yacon.

\begin{tabular}{|c|c|c|c|c|c|c|c|c|c|c|c|c|c|c|c|c|}
\hline \multirow{3}{*}{ Items evaluated } & \multicolumn{8}{|c|}{$\begin{array}{l}\text { Chocolate and carrot cakes } \\
\text { prepared with yacon in natura }\end{array}$} & \multicolumn{8}{|c|}{$\begin{array}{l}\text { Chocolate and carrot cakes } \\
\text { prepared with yacon flour }\end{array}$} \\
\hline & \multicolumn{4}{|c|}{ 1st day } & \multicolumn{4}{|c|}{ 2nd day } & \multicolumn{4}{|c|}{ 3rd day } & \multicolumn{4}{|c|}{ 4th day } \\
\hline & CChCSu & T1 & $\mathrm{CChCSw}$ & T3 & $\mathrm{CCaCSu}$ & C1 & $\mathrm{CCaCSw}$ & C3 & CChCSu & $\mathbf{T 2}$ & CChCSw & T4 & $\mathrm{CCaCSu}$ & $\mathrm{C2}$ & $\mathrm{CCaCSw}$ & C4 \\
\hline Taste & $7.94^{\mathrm{a}}$ & $7.26^{\mathrm{b}}$ & $7.68^{\mathrm{ab}}$ & $7.61^{\mathrm{ab}}$ & $7.60^{\mathrm{a}}$ & $6.84^{\mathrm{ab}}$ & $6.44^{\mathrm{b}}$ & $6.18^{\mathrm{b}}$ & $7.62^{\mathrm{a}}$ & $7.24^{\mathrm{a}}$ & $7.26^{\mathrm{a}}$ & $7.54^{\mathrm{a}}$ & $7.67^{\mathrm{a}}$ & $6.30^{\mathrm{b}}$ & $7.42^{\mathrm{a}}$ & $6.18^{b}$ \\
\hline Texture & $7.98^{\mathrm{a}}$ & $7.84^{\mathrm{a}}$ & $7.47^{\mathrm{a}}$ & $7.38^{\mathrm{a}}$ & $8.00^{\mathrm{a}}$ & $7.10^{\mathrm{b}}$ & $6.17^{\mathrm{c}}$ & $7.03^{\mathrm{b}}$ & $7.64^{\mathrm{a}}$ & $6.58^{\mathrm{b}}$ & $7.10^{\mathrm{ab}}$ & $7.26^{\mathrm{ab}}$ & $7.65^{\mathrm{a}}$ & $6.03^{\mathrm{b}}$ & $6.94^{\mathrm{ab}}$ & $6.17^{\mathrm{b}}$ \\
\hline Appearance & $7.92^{\mathrm{a}}$ & $8.19^{\mathrm{a}}$ & $8.21^{\mathrm{a}}$ & $7.85^{\mathrm{a}}$ & $8.20^{\mathrm{a}}$ & $5.87^{\mathrm{bc}}$ & $6.53^{\mathrm{b}}$ & $5.22^{c}$ & $7.56^{\mathrm{a}}$ & $6.54^{\mathrm{b}}$ & $7.18^{\mathrm{ab}}$ & $6.98^{\mathrm{ab}}$ & $7.78^{\mathrm{a}}$ & $5.61^{\mathrm{b}}$ & $7.88^{\mathrm{a}}$ & $5.26^{\mathrm{b}}$ \\
\hline Color & $8.15^{\mathrm{a}}$ & $8.29^{\mathrm{a}}$ & $8.22^{\mathrm{a}}$ & $8.17^{\mathrm{a}}$ & $8.34^{\mathrm{a}}$ & $5.34^{\mathrm{c}}$ & $7.25^{\mathrm{b}}$ & $4.81^{\mathrm{c}}$ & $7.62^{\mathrm{a}}$ & $7.14^{\mathrm{a}}$ & $7.38^{\mathrm{a}}$ & $7.40^{\mathrm{a}}$ & $7.88^{\mathrm{a}}$ & $5.50^{\mathrm{b}}$ & $7.98^{\mathrm{a}}$ & $5.19^{\mathrm{b}}$ \\
\hline Overall acceptance & $7.92^{\mathrm{a}}$ & $7.43^{\mathrm{a}}$ & $7.64^{\mathrm{a}}$ & $7.64^{\mathrm{a}}$ & $7.91^{\mathrm{a}}$ & $6.44^{\mathrm{b}}$ & $6.25^{\mathrm{b}}$ & $6.06^{\mathrm{b}}$ & $7.54^{\mathrm{a}}$ & $7.10^{\mathrm{a}}$ & $7.08^{\mathrm{a}}$ & $7.42^{\mathrm{a}}$ & $7.61^{\mathrm{a}}$ & $5.75^{\mathrm{b}}$ & $7.48^{\mathrm{a}}$ & $5.75^{\mathrm{b}}$ \\
\hline Purchase intent & $8.15^{\mathrm{a}}$ & $7.73^{\mathrm{a}}$ & $7.59^{\mathrm{a}}$ & $8.01^{\mathrm{a}}$ & $7.56^{\mathrm{a}}$ & $5.43^{\mathrm{b}}$ & $5.65^{\mathrm{b}}$ & $4.87^{\mathrm{b}}$ & $7.68^{\mathrm{a}}$ & $6.40^{\mathrm{a}}$ & $6.70^{\mathrm{a}}$ & $7.22^{\mathrm{a}}$ & $7.44^{\mathrm{a}}$ & $4.76^{\mathrm{b}}$ & $7.05^{\mathrm{a}}$ & $4.88^{\mathrm{b}}$ \\
\hline
\end{tabular}

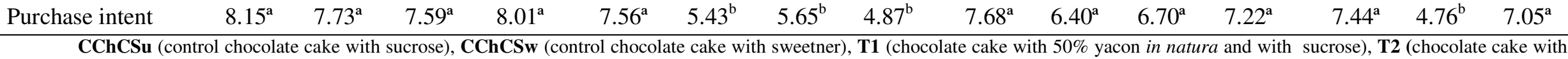
$70 \%$ yacon flour and sucrose), T3 (chocolate cake with $50 \%$ yacon in natura and sweetner), T4 (chocolate cake with $70 \%$ yacon flour and sweetner). CCaCSu (control carrot cake with sucrose), CCaCSw (control carrot cake with sweetner), $\mathbf{C 1}$ (carrot cake with 50\% yacon in natura and with sucrose), $\mathbf{C 2}$ (carrot cake with $70 \%$ yacon flour and with sucrose), $\mathbf{C 3}$ (carrot cake with 50\% yacon in natura and with sweetner), $\mathbf{C 4}$ (carrot cake with $70 \%$ yacon flour and with sweetner). *Same letters in the same line indicate no significant difference between the means ( $>0.05$ - Tukey test), considering each block (day) of evaluation individually. 
Table 4. Chemical composition of chocolate and carrot cakes made with yacon.

\begin{tabular}{|c|c|c|c|c|c|c|c|c|}
\hline \multirow{2}{*}{ Composition (g/100g) } & \multicolumn{4}{|c|}{$\begin{array}{c}\text { Chocolate cakes made with yacon in natura } \\
\text { and yacon flour }\end{array}$} & \multicolumn{4}{|c|}{$\begin{array}{c}\text { Carrot cakes made with yacon in natura } \\
\text { and yacon flour }\end{array}$} \\
\hline & T1 & $\mathbf{T 2}$ & T3 & T4 & C1 & $\mathbf{C 2}$ & $\mathrm{C3}$ & $\mathrm{C} 4$ \\
\hline Moisture & $39.78 \pm 0.25^{\mathrm{b}}$ & $21.05 \pm 0.35^{\mathrm{e}}$ & $43.90 \pm 0.14^{\mathrm{a}}$ & $32.05 \pm 0.16^{\mathrm{c}}$ & $40.27 \pm 0.02^{\mathrm{b}}$ & $19.87 \pm 0.04^{\mathrm{f}}$ & $43.31 \pm 0.16^{\mathrm{a}}$ & $30.43 \pm 0.47^{\mathrm{d}}$ \\
\hline Protein & $12.63 \pm 0.25^{\mathrm{ab}}$ & $12.52 \pm 1.09^{\mathrm{ab}}$ & $12.12 \pm 0.99^{\mathrm{ab}}$ & $10.64 \pm 0.17^{\mathrm{b}}$ & $11.15 \pm 0.79^{\mathrm{ab}}$ & $10.40 \pm 0.55^{\mathrm{b}}$ & $14.96 \pm 1.24^{\mathrm{a}}$ & $11.78 \pm 1.05^{\mathrm{ab}}$ \\
\hline Lipids & $17.59 \pm 0.80^{\mathrm{d}}$ & $11.18 \pm 0.57^{\mathrm{e}}$ & $16.73 \pm 0.55^{\mathrm{d}}$ & $20.82 \pm 0.06^{\mathrm{c}}$ & $28.60 \pm 0.19^{b}$ & $20.83 \pm 0.28^{\mathrm{c}}$ & $29.71 \pm 0.28^{\mathrm{b}}$ & $31.88 \pm 0.08^{\mathrm{a}}$ \\
\hline Ash & $3.74 \pm 0.24^{\mathrm{a}}$ & $3.73 \pm 1.39^{\mathrm{a}}$ & $4.39 \pm 0.57^{\mathrm{a}}$ & $3.11 \pm 0.06^{\mathrm{a}}$ & $3.38 \pm 0.26^{\mathrm{a}}$ & $4.53 \pm 0.19^{\mathrm{a}}$ & $4.16 \pm 0.19^{\mathrm{a}}$ & $4.16 \pm 0.28^{\mathrm{a}}$ \\
\hline Dietary fiber & $0.44 \pm 0.03^{b}$ & $10.10 \pm 0.06^{\mathrm{a}}$ & $0.45 \pm 0.02^{\mathrm{b}}$ & $11.52 \pm 0.07^{\mathrm{a}}$ & $0.48 \pm 0.02^{b}$ & $11.15 \pm 0.06^{\mathrm{a}}$ & $0.52 \pm 0.02^{b}$ & $13.90 \pm 0.08^{\mathrm{a}}$ \\
\hline Oligofructans & $0.17 \pm 0.02^{\mathrm{b}}$ & $4.14 \pm 0.04^{\mathrm{a}}$ & $0.17 \pm 0.03^{\mathrm{b}}$ & $4.72 \pm 0.05^{\mathrm{a}}$ & $0.18 \pm 0.02^{b}$ & $4.57 \pm 0.07^{\mathrm{a}}$ & $0.20 \pm 0.01^{\mathrm{b}}$ & $5.69 \pm 0.07^{\mathrm{a}}$ \\
\hline Available carbohydrates & $25.82 \pm 0.55^{\mathrm{d}}$ & $41.42 \pm 1.71^{\mathrm{a}}$ & $22.41 \pm 1.98^{\mathrm{d}}$ & $21.86 \pm 0.12^{\mathrm{c}}$ & $16.12 \pm 1.28^{\mathrm{e}}$ & $33.22 \pm 0.50^{\mathrm{b}}$ & $7.34 \pm 1.44^{\mathrm{f}}$ & $7.85 \pm 1.39^{\mathrm{d}}$ \\
\hline Total carbohydrates & $26.26 \pm 0.47^{\mathrm{d}}$ & $51.52 \pm 1.25^{\mathrm{a}}$ & $22.86 \pm 1.65^{\mathrm{d}}$ & $33.38 \pm 0.24^{\mathrm{c}}$ & $16.60 \pm 1.14^{\mathrm{e}}$ & $44.37 \pm 0.67^{b}$ & $7.86 \pm 1.42^{\mathrm{f}}$ & $21.75 \pm 1.54^{\mathrm{d}}$ \\
\hline Energetic value (kcal) & $313.87 \pm 1.09^{\mathrm{e}}$ & $356.78 \pm 1.31^{\mathrm{d}}$ & $290.51 \pm 1.04^{\mathrm{f}}$ & $343.44 \pm 0.72^{\text {cd }}$ & $368.34 \pm 0.16^{\mathrm{c}}$ & $426.54 \pm 1.33^{b}$ & $358.66 \pm 1.38^{\mathrm{cd}}$ & $421.04 \pm 1.45$ \\
\hline
\end{tabular}

T1 (Chocolate cake with 50\% yacon in natura and with sucrose), T2 (chocolate cake with 70\% yacon flour and sucrose), T3 (chocolate cake with 50\% yacon in natura and sweetner), $\mathbf{T 4}$ (chocolate cake with $70 \%$ yacon flour and sweetner). C1 (carrot cake with 50\% yacon in natura and with sucrose), C2 (carrot cake with $70 \%$ yacon flour and with sucrose), C3 (carrot cake with $50 \%$ yacon in natura and with sweetner), $\mathbf{C 4}$ (carrot cake with $70 \%$ yacon flour and with sweetner). Same letters in the same line indicate no significant difference between the results (p>0.05 - Tukey Test) 
Moscatto et al. (2004) showed moisture content at about $38 \%$ for chocolate cakes made with $40 \%$ of yacon flour replacing wheat. Regarding protein, all cakes were very similar to each other, averaging around $12 \mathrm{~g} / 100 \mathrm{~g}$. The lipid content was higher in the carrot cakes since the formula of these cakes had more vegetable oil. In regard to the mineral residue (ash), there was no difference between the formulas as observed by Moscatto et al. (2004). The dietary fiber content of cakes made with yacon flour was superior to those cakes containing yacon in natura. The cakes made with $70 \%$ yacon flour, regardless of the use of sucrose or not and their flavor, can be considered foods high in dietary fiber (BRAZIL, 2012). The cakes made with $70 \%$ yacon flour had higher oligofructan content. Considering a $60 \mathrm{~g}$ portion of the product, cakes made with $70 \%$ yacon flour fit within the parameters of functional foods, given their dietary fiber content (BRAZIL, 2008). However, due to the content of oligofructans present in the samples, only the sample $\mathrm{C} 4$ (diet carrot cake with $70 \%$ yacon flour) can be considered a product with bioactive components.

We note that yacon consumption is still very small in the Brazilian population. The insertion of this tuberose in food and bakery products is still a challenge. The use of yacon flour requires special equipment, which requires time and more costs to the final product. However, its use in nature is possible and feasible considering the homemade preparation.

\section{CONCLUSIONS}

The cakes prepared with $50 \%$ yacon in natura with the addition of sucrose in the formula had physical aspects closer to conventional cakes.

The yield of the cakes around $90 \%$ was considered satisfactory, regardless of the use of yacon in natura or as flour.

The chocolate cakes obtained higher rates regarding sensory attributes and purchase intention than the carrot cakes, especially when yacon in natura was used in their formulation.

The cakes containing sweetener were rated as good as those with sucrose, especially regarding the flavor of the chocolate cakes.

The cakes made with $70 \%$ yacon flour had higher dietary fiber content as well as fructooligosaccharides. If the sucrose is excluded, this ingredient must be replaced by sweeteners comprised of structuring agents such as maltodextrin. Furthermore, the use of growth favoring agents, such as the enzymes amylases, as well as the addition of gluten, contributes to obtaining baked products with desirable physical and sensory characteristics.

\section{ACKNOWLEDGEMENTS}

The Associate Dean of Research and PostGraduate Studies of Federal University of Espirito Santo - Pró-Reitoria de Pesquisa e Pós-Graduação da Universidade Federal do Espírito Santo (PRPPGUFES) - Programa de Iniciação Científica.

RESUMO: O yacon é uma raiz tuberosa que possui em sua composição, componentes bioativos como frutooligossacarídeos (FOS). O objetivo deste estudo foi avaliar características físico-químicas e sensoriais de bolos diet e convencionais elaborados com yacon in natura e sua respectiva farinha. Foram elaborados bolos, nos sabores chocolate e cenoura, com adição de 50\% de yacon in natura e 70\% de farinha de yacon. Os bolos elaborados com 50\% de yacon in natura, com a adição de sacarose na formulação apresentaram aspectos físicos mais próximos aos bolos convencionais. $\mathrm{O}$ rendimento dos bolos, em torno de $90 \%$ foi considerado satisfatório, independente da utilização do yacon in natura ou farinha. Os bolos de chocolate obtiveram notas mais elevadas quanto aos atributos sensoriais e intenção de compra, em relação aos bolos de cenoura, em especial quando se utilizou o yacon in natura nas formulações. Os bolos contendo adoçante foram tão bem avaliados quanto àqueles que possuíam sacarose, em especial, em relação ao sabor dos bolos de chocolate. De acordo com a composição química, os bolos com $70 \%$ de farinha yacon apresentaram maiores teores de fibra alimentar bem como de FOS, sendo considerados alimentos com alto teor de fibras, sugerindo-se também sua alegação como um componente bioativo.

PALAVRAS-CHAVE: Smallanthus sonchifolius. Bolos. Composição química. Nutrição. Bioativo. Frutooligossacarídeos. 


\section{REFERENCES}

AKESOWAN, A. Quality of reduced-fat chiffon cakes prepared with erythritol-sucralose as replacement for sucrose. Pakistan J. Nutr., Faisalabad, v. 8, n. 9, p. 1383-1386, 2009. http://dx.doi.org/10.3923/pjn.2009.1383.1386

AMERICAN ASSOCIATION OF CEREAL CHEMISTS - AACC. Approved methods of the AACC. 9. ed. Saint Paul, 1995. 1005 p.

ARAÚJO, M. O. D.; GUERRA, T. M. M. Alimentos "Per Capita”. 2. ed. Natal: Editora Universitária UFRN, 1995. 272p.

ASSOCIATION OF OFFICIAL AGRICULTURAL CHEMISTS - AOAC. Official Methods of Analysis of the Association of Official Agriculture Chemists. 18. ed. Gaithersburg, 2005, 1200 p.

BRASIL. Agência Nacional de Vigilância Sanitária. Lista de alegação de propriedade funcional. Atualizada em julho de 2008. Available at: <http://www.anvisa.gov.br/alimentos/comissoes/tecno_lista_alega.htm>. Accessed on: March 30, 2015.

BRASIL. Agência Nacional de Vigilância Sanitária. Resolução RDC n54, de 12 de novembro de 2012. Dispõe sobre o Regulamento Técnico sobre Informação Nutricional Complementar. Available at: <http://portal.anvisa.gov.br/wps/wcm/connect/630a98804d7065b981f1e1c116238c3b/Resolucao+RDC+n.+54_ 2012.pdf?MOD=AJPERES>. Accessed on: March 23, 2015.

CAMPOS, D.; BETALLELUZ-PALLARDEL, I.; CHIRINOS, R.; AGUILAR-GALVEZ, A.; NORATTO, G.; PEDRSCHI, R. Prebiotic effects of yacon (Smallanthus sonchifolius Poepp. \& Endl), a source of fructooligosaccharides and phenolic compounds with antioxidant activity. Food Chem., v. 135, p. 1592-1599, 2012. http://dx.doi.org/10.1016/j.foodchem.2012.05.088

DElGAdO, G. T. C.; TAMASHIRO, W. M. S. C.; JUNIOR, M. R. M.; PASTORE, G. M. Yacon (Smallanthus sonchifolius): A Functional Food. Plant Foods Hum. Nutr., New York, v. 68, p. 222-228, 2013. http://dx.doi.org/10.1007/s11130-013-0362-0

DUTCOSKY, S. D. Análise Sensorial de Alimentos. 2. ed. Curitiba: Editora Universitária Champagnat, 2007. $239 \mathrm{p}$.

ESTELLER, M. S.; LANNES, S. C. S. Parâmetros complementares para fixação de identidade e qualidade de produtos panificados. Ciênc. Tecnol. Aliment., Campinas, v. 25, n. 4, p. 802-806, 2005. http://dx.doi.org/10.1590/S0101-20612005000400028

ESTELLER, M. S.; YOSHIMOTO, R. M. O.; AMARAL, R. L.; LANNES, S. C. S. Uso de açúcares em produtos panificados. Ciênc. Tecnol. Aliment., Campinas, v. 24, n. 4, p. 602-607, 2004. http://dx.doi.org/10.1590/S0101-20612004000400021

GENTA, S. B.; CABRERA, W. M.; GRAU, A.; SÁNCHEZ, S. S. Subchronic 4-month oral toxicity study of dried Smallanthus sonchifolius (yacon) roots as a diet supplement in rats. Food Chem. Toxicol., v. 43, n. 11, p. 1657-1665, 2005. http://dx.doi.org/10.1016/j.fct.2005.05.007

GOMEZ, M.; RONDA, F.; BLANCO, C. A.; CABALLERO, P. A.; APESTEGUÍA, A. Effect of dietary fibre on dough rheology and bread quality. Euro. Food Res. Tec., Berlin, v. 216, n. 1, p. 51-56, 2003. http://dx.doi.org/10.1007/s00217-002-0632-9

GUIGOZ, Y.; ROCHAT, F.; PERRIUSSEAU-CARRIER, G.; ROCHAT, J.; SCHIFFRIN, E.J. Effects of oligosaccharides on the faecal flora and non-specific immune system in elderly people. Nutr. Res., v. 22, p. 13-25, 2002. http://dx.doi.org/10.1016/S0271-5317(01)00354-2 
GUIMARÃES, R.R.; BOEKEL, S. V. Elaboração de suco de maracujá enriquecido com frutooligossacarídeos a partir da utilização da polpa de Yacon (Smallanthus sonchifolius). Rev. Nutr. Bras., São Paulo, v. 5, n. 6, p. 308-314, 2006.

MALDONADO, S.; SANTAPAOLA, J. E.; SINGH, J.; TORREZ, M.; GARAY, A. Cinética de la transferencia de masa durante la deshidratación osmótica de yacón (Smallanthus sonchifolius). Ciênc. Tecnol. Aliment., Campinas, v. 28, n. 1, p. 251-256, 2008. http://dx.doi.org/10.1590/S0101-20612008000100036

MALDONADO, S.; SINGH, J. D. C. Efecto de gelificantes en la formulación de dulce de yacón. Ciênc. Tecnol. Aliment., Campinas, v. 28, n. 2, p. 429-434, 2008. http://dx.doi.org/10.1590/S010120612008000200025

MOSCATTO, J. A.; PRUDÊNCIO - FERREIRA, S. H.; HAULY, C. O. M. Farinha de yacon e inulina como ingredientes na formulação de bolo de chocolate. Ciênc. Tecnol. Aliment., Campinas, v. 24, n. 4, p. 634-640, 2004. http://dx.doi.org/10.1590/S0101-20612004000400026

OJANSIVU, I.; FERREIRA, C. L.; SALMINEN, S. Yacon, a new source of prebiotic oligosaccharides with a history of safe use. Trends Food Sci. Technol., v. 22, p. 40-46, 2011. http://dx.doi.org/10.1016/j.tifs.2010.11.005

PADILHA, V. M.; ROLIM, P. M.; SALGADO, S. M.; LIVERA, A. V. S.; OLIVEIRA, M. G. Drying time and yacon (Smallanthus sonchifolius) enzymatic activity inhibition under chemical treatment. Ciênc. Rural, Santa Maria, v. 39, n. 7, p. 2178-2184, 2009. http://dx.doi.org/10.1590/S0103-84782009005000142

PADILHA, V. M.; ROLIM, P. M.; SALGADO, S. M.; LIVERA, A. S.; ANDRADE, S. A. C.; GUERRA, N.B. Perfil sensorial de bolos de chocolate formulados com farinha de yacon (Smallanthus sonchifolius). Ciênc. Tecnol. Aliment., Campinas, v. 30, n. 3, p. 755-740, 2010. http://dx.doi.org/10.1590/S010120612010000300026

PASSOS, L. M. L.; PARK, Y. K. Frutooligossacarídeos: implicações na saúde humana e utilização em alimentos. Ciênc. Rural, Santa Maria, v. 33, n. 2, p. 385-390, 2003. http://dx.doi.org/10.1590/S010384782003000200034

REBELO, A. M.; CASALI, E. Z.; BERTOLDI, F. C. Controle de escurecimento enzimático em chips de yacon. Evidência, Joaçaba, v. 8, n. 1-2, p. 7-16, 2008.

RIBEIRO, J. A. Estudo químico e bioquímico do yacon (Smallanthus sonchifolius) in natura $\mathrm{e}$ processado e influência do consumo de yacon sobre níveis glicêmicos e lipídeos fecais de ratos. 2008. 166 f. Dissertação (Mestrado em Ciências dos Alimentos) - Curso de Pós-Graduação em Ciência dos Alimentos, Universidade Federal de Lavras, Minas Gerais, 2008.

ROBERFROID, M. B.; GIBSON, G. R.; DELZENNE, N. The Biochemistry of oligofructose, a nondigestible fiber: An approach to calculate its caloric value. Nutr. Rev., v. 51, n. 5, p. 137-146, 1993. http://dx.doi.org/10.1111/j.1753-4887.1993.tb03090.x

ROLIM, P. M.; SALGADO, S. M.; PADILHA, V. M.; LIVERA, A. V. S.; GUERRA, N. B.; ANDRADE, S. A. C. Glycemic profile and prebiotic potential "in vitro" of bread with Yacon (Smallanthus sonchifolius) flour. Ciênc. Tecnol. Aliment., Campinas, v. 31, n. 2, p. 467- 474, 2011. http://dx.doi.org/10.1590/S010120612011000200029

ROSA, C. S.; OLIVEIRA, V. R.; VIEIRA, V. B.; GRESSLER, C.; VIEGA, S. Elaboração de bolo com farinha de yacon. Ciênc. Rural, Santa Maria, v. 39, n. 6, p. 1869-72, 2009. http://dx.doi.org/10.1590/S010384782009005000131 
SALVADOR, A. C.; DANTAS, M. I. S.; VASCONCELOS, C. M.; VANETTI, M. C. D.; RIBEIRO, S. M. R.; NERY-ENES, B.; NELSON, J. D.; MARTINO, H. S. D. Desarrollo de jalea de yacón de reducido valor calórico: caracterización físico-química, microbiológica y sensorial. Rev. Chil. Nutr., Santiago, v. 39, n. 3, p. 72-77, 2012. http://dx.doi.org/10.4067/S0717-75182012000300011

SANTANA, I.; CARDOSO, M. H. Raiz tuberosa de yacon (Smallanthus sonchifolius): potencialidade de cultivo, aspectos tecnológicos e nutricionais. Ciênc. Rural, Santa Maria, v. 38, n. 3, p. 898- 905, 2008. http://dx.doi.org/10.1590/S0103-84782008000300050

SARAIVA, S. H.; ZEFERINO, L. B.; JUNQUEIRA, M. S.; SILVA, L. C.; TEIXEIRA, L. J. Q. Avaliação de agentes preservantes do escurecimento enzimático no processo de secagem de maçã. Enciclopédia biosfera, Goiânia, v. 6, n. 11, p. 1-8, 2010.

SILVA, M. T. P.; SILVA, C. B.; PALEO, I. W.; CHANG, Y. K. Utilização de frutooligossacarídeos na elaboração de pão de forma sem açúcar. Temas Agr., Montería, v. 15, n. 1, p. 44-57, 2010.

VASCONCElOS, C. M.; SILVA, C. O.; TEIXEIRA, L. J. Q.; CHAVES, J. B. P.; MARTINO, H. S. D. Determinação da fração da fibra alimentar solúvel em raiz e farinha de yacon (Smallanthus sonchifolius) pelo método enzimático-gravimétrico e cromatografia líquida de alta eficiência. Rev. Inst. Adolfo Lutz, São Paulo, v. 69 , n. 2, p. $188-193,2010$.

VASCONCELOS, C. M. Caracterização físico-química e sensorial de iogurte "light" com farinha de yacon (Smallanthus sonchifolius). 2010. 56f. Dissertação (Mestrado em Ciência e Tecnologia de Alimentos) - Curso de Pós-Graduação em Ciência e Tecnologia de Alimentos, Universidade Federal de Viçosa, Viçosa, 2010.

VOS, A. P.; VAN ESCH, B. C.; STAHL, B.; M'RABET, L.; FOLKERTS, G.; NIJKAMP, F. P.; GARSSEN, J. Dietary supplementation with specific oligosaccharide mixtures decreases parameters of allergic asthma in mice. Int. Immunopharmacol, Bethesda, v. 7(Suppl 12), p. 1582-1587, 2007. 